DOI: https://doi.org/10.31933/dijms.v2i3

Received: 24 November 2020, Revised: 25 December 2020, Publish: 24 January 2021

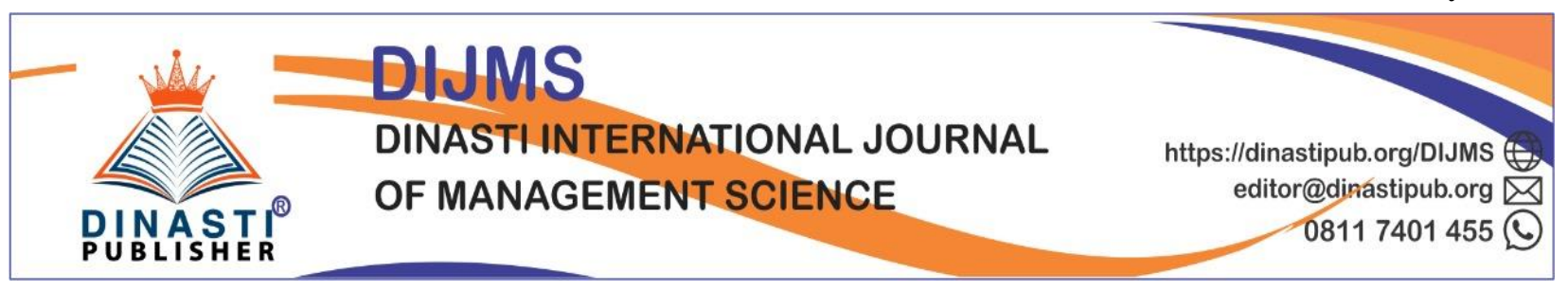

\title{
ANALYSIS OF THE INFLUENCE OF SERVICE QUALITY ON CUSTOMER LOYALTY AT E-COMMERCE SHOPEE IN THE COVID- 19 PANDEMIC
}

\author{
Suyono Salamun ${ }^{1}$, Cahyani Kurniastuti², Subaebasni Subaebasni ${ }^{3}$ \\ ${ }^{1)}$ Politeknik Bisnis dan Pasar Modal, Suyono.salamun@gmail.com \\ 2) Universitas Muhammadiyah Tangerang, Safa.Raihan@gmail.com \\ 3) PT. Al Badriyah Wisata, subaebasni.sarbini@gmail.com
}

\section{Corresponding Author: First Author}

\begin{abstract}
The purpose of this study is to analyze of the Influence of reliability, assurance, tangibles, empathy, and responsiveness on Customer Loyalty at E-commerce Shopee in the COVID-19 Pandemic. The research methodology is a quantitative method with cross-section data and primary data obtained from questionnaire distribution. Sampling technique using purposive sampling method with data in 2020. The data analysis technique is multiple linear regression by conducting validity test, reliability test, model stability test, linearity test, normality test, classical assumption test (multicollinearity test, heteroscedasticity test) and test of t-statistic hypothesis and f-statistic on test significance of impact together with 5\% significance level The results of this study indicate in partial variables of reliability, assurance, tangibles, empathy, and responsiveness have a positive impact and significant on Customer Loyalty at E-Commerce Shopee. Meanwhile, the independent variables of reliability, assurance, tangibles, empathy, and responsiveness collectively have a significant relationship with the dependent variable of Costumer Loyalty at E-Commerce Shopee. The Coefficient of determination of this research equally to $84,42 \%$, it means variation of the independent variables of reliability, assurance, tangibles, empathy, and responsiveness can explain the variations of the rise and fall of the dependent variable of Customer Loyalty on E-Commerce Shopee by $84,42 \%$, while the rest of 15,58\%, is influenced by other independent variables.
\end{abstract}

Keywords: Reliability, Assurance, Tangibles, Empathy, Responsiveness, Customer Loyalty

\section{INTRODUCTION}

The rapid development of technology has brought the world into a new era that is faster than previously imagined. There have been several important eras since the first discovery of computers as data processing tools to the era of the internet, where the main thing in getting information quickly is the internet itself.

As of April 2017, more than 3.8 billion people worldwide use the internet, indicating that the majority of internet users worldwide reach $51 \%$. 
Data penetration of internet users by region in Indonesia in 2017 according to the Indonesian Internet Service Providers Association (Indonesia Internet Exchange), the number of internet users in Indonesia in 2017 was 143.26 million users or around $54.68 \%$ of the total population of Indonesia.

262 million people. Most internet users are in Java Island with internet users of 58.08\%, then Sumatra Island 19.09\%, Kalimantan Island 7.97\%, Sulawesi Island 6.73\%, Bali-NTBNTT $5.63 \%$, and Maluku -Papua 2.49\%. This is very encouraging, especially for entrepreneurs or online shop owners, especially in Java.

Based on data from Indonesia Internet Exchange, it shows that the largest number of internet users in Indonesia are aged 19-34 years, amounting to $49.52 \%$ or 70.94 million users.

The very rapid development of the digital world has become a field for business people to expand their business wings into the online realm. In fact, the development of online shops or online shops through internet media has mushroomed in Indonesia, as seen from the number of transactions that have always increased from 2011 to 2015, and are even well known by the public. Various kinds of convenience in shopping and various types of products and services offered have made Indonesians use the online shop as a place to shop for goods or services.

This makes many companies or sellers compete to provide online services or offer their products online in various ways to attract consumers to shop, either as a substitute or as an addition to their offline services. This condition is exploited by companies or sellers where online shopping is in great demand by the world community even in Indonesia today.

The growth of e-commerce that continues to increase in Indonesia makes one of the applications Shopee participate in enlivening the e-commerce industry. Shopee is one of the many parties taking advantage of the e-commerce business opportunity by enlivening the mobile marketplace segment through their mobile application to simplify buying and selling transactions via mobile devices.

Shopee's approach as an e-commerce application platform can also be seen from several excellent features such as chat and bargaining. These features are presented to facilitate buying and selling activities at Shopee. Security features in Shopee must have a unique user identification (User ID) and password, then Shopee asks users to maintain personal confidentiality, log out of the account at the end of each session, notify Shopee of unauthorized use of user accounts, and ensure that user account information accurate and current. If an irregularity is found in a user account and it is used by a third party, Shopee will terminate the account and User ID to ensure the safety of both the account owner and Shopee. (shopee.co.id)

The services provided by Shopee are customer service support via email, SMS and feedback forms. Users can post questions and answer questions from other Users on the Shopee community forums. In order to face the intensity of the increasingly severe challenges, companies in running their business are required to think creatively to find various breakthrough strategies that can create synergies that contribute optimally to the achievement of their company goals. (shopee.co.id)

For this reason, companies are required to be able to implement strategic policies regarding services in the telecommunications sector in order to anticipate an increasingly competitive climate of competition. One of the most important elements in an organization is the excellence of its service. Excellence in service in an organization or company, at least can 
be the success of a company in facing all challenges and threats that will hinder the pace of company development in the future. (shopee.co.id)

In a business that focuses on customers, it can be said that service quality is the only determining factor of the company's existence in being involved in an industry or business that is full of competition, because if service quality is not considered, then the consequence is that the customer will move to the industry or business. other similar ones that provide more satisfying service and provide good complaint responses to consumers. (Kotler and Keller, 2009)

Seeing this, Shopee is one of the largest online stores in Indonesia with good service quality. Optimal service quality can be used as a company strategy to increase and retain customers. Good service quality is very influential for the survival of the company. Good service quality will make customers loyal to continue using these services. Likewise, the creation of an optimal level of customer satisfaction encourages loyalty in the minds of satisfied customers. (Sigit and Oktafani, 2014).

Service Quality includes 5 dimensions, namely:

1. Reliability

The Reliability dimension relates to the company's ability to provide accurate service from the first time without making any mistakes and delivering its services according to the agreed time. In previous research conducted by Sigit and Oktafani (2014) which resulted in the conclusion that Reliability has a positive and significant effect on customer satisfaction.

2. Assurance

The Assurance dimension informs the behavior of employees that is able to foster customer trust in the company and the company can create a sense of security for its customers. Assurance also means that employees are always courteous and have the knowledge and skills needed to handle every customer question and problem. In previous research conducted by Panjaitan and Yuliati (2016) concluded that Assurance has a positive and significant effect on customer satisfaction.

3. Tangible

Tangible with regard to the attractiveness of the physical facilities, equipment and materials used by the company, as well as the appearance of employees. In previous research conducted by Pratama, Tannady and Jodiawan (2017) concluded that Tangible has a positive and significant effect on customer satisfaction.

4. Empathy

Empathy means that the company understands the problems of its customers and acts in the interests of customers, as well as giving personal attention to customers and having comfortable operating hours. In previous research conducted by Marina, Darmawati and Setiawan (2014) concluded that Empathy has a positive and significant effect on customer satisfaction.

5. Responsiveness 
Responsiveness refers to the willingness and ability of employees to help customers and respond to their requests, as well as informing when services will be provided and then providing services appropriately. In previous research conducted by Khoirista, Yulianto and Mawardi (2015), the conclusion is that Responsiveness has a positive and significant effect on customer loyalty.

Customer satisfaction with the services provided by the company will be known when measuring and testing consumers. Service is considered satisfactory if the service can meet the needs and expectations of consumers. Measuring customer satisfaction is an important element in providing better, more efficient and more effective service. The use of service quality dimensions as a measuring tool that is expected by a company to determine the level of customer satisfaction. By knowing the results of measuring customer satisfaction, the company can prepare strategies that will later be implemented in order to create consumer loyalty.

Consumer loyalty can be used as a basis or benchmark in making policies to add or reduce product value for consumers. Where the company will obtain information from consumers, namely regarding the activities of interpreting, processing, and storing information about products and brands. Therefore, customer loyalty can affect consumer confidence in making purchasing decisions. Consumer loyalty can show how much support a consumer has for the product or service offered by the company. On the other hand, consumer loyalty can prove the level of consumer confidence in the products or services offered by the company. (Khoirista, Yulianto and Mawardi. 2015)

Along with the increasing demands of society regarding the need for quality services and services, this is a challenge for a company as well as an opportunity for them to meet the needs and desires of consumers. Based on these circumstances, the company is expected to always conduct an evaluation of the quality of services provided so far, so that it can be used as evaluation material in achieving the company's goals maximally and in an effort to create consumer loyalty.

Based on the research background above, the authors are interested in making a thesis with the title "Analysis of the Influence of Service Quality on Consumer Loyalty in Shopee ECommerce during the Covid 19 Period".

\section{LITERATURE REVIEW}

\section{Understanding Marketing Management}

Marketing (marketing) is identifying and meeting human and social needs. One good and short definition of marketing is "making ends meet in a profitable way". (Kotler and Keller, 2009: 5)

\section{Services}

Lamb and McDaniel (2001) define service as "the result of the use of humans and machines on people or objects. Services include performance acts, or efforts that cannot be processed physically". (Wijaya, 2012: 5)

\section{Reliability}

Reliability relates to the company's ability to provide accurate service from the first time without making any mistakes and deliver its services according to the agreed time. (Pasuraman, Zeithmal, and Berry in the book Tjiptono, Chandra, 2011: 198) 


\section{Assurance}

Assurance, with respect to the knowledge and courtesy of employees and their ability to foster trust and customer confidence. (Pasuraman, Zeithmal, and Berry in the book Tjiptono, 2012: 175)

\section{Tangible (Conclusive evidence)}

Tangible with respect to the attractiveness of the physical facilities, equipment and materials used by the company, as well as the appearance of employees. (Pasuraman, Zeithmal, and Berry in the book Tjiptono, Chandra, 2011: 198)

\section{Empathy}

Empathymeans that the company understands the problems of its customers and acts in the interest of the customers, and pays personal attention to customers and has comfortable hours of operation. (Pasuraman, Zeithmal, and Berry in the book Tjiptono, Chandra, 2011: 198)

\section{Responsiveness}

Responsiveness, refers to the willingness and ability of service providers to help customers and respond to their requests immediately. (Pasuraman, Zeithmal, and Berry in the book Tjiptono, 2012: 175)

\section{Consumer Loyalty}

According to Kotler and Keller (2009: 138)expressing loyalty is "a deeply held commitment to buy or repurchase a preferred product or service in the future even though the influence of the situation and marketing efforts have the potential to cause customers to switch".

\section{Electronic Commerce}

Electronic Commerce or E-Commerce is a buying and selling process that takes place via the internet. Usually by means of, buyers visit a website and make transactions there, but the role of the internet is much bigger than that. (Sumarwan, et al, 2011: 287) 


\section{Conceptual framework}

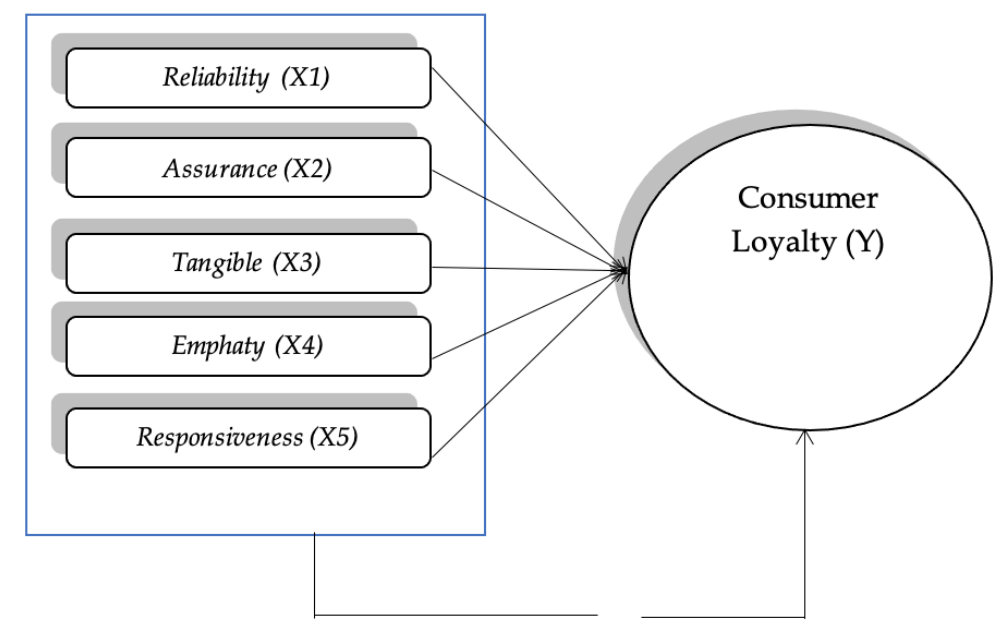

Figure 1. Conceptual framework

\section{RESEARCH METHODS}

Research as a way to solve a problem or find answers to problems faced scientifically, uses reflective thinking, scientific thinking with procedures that are in accordance with the objectives and nature of the investigation. Scientific research uses steps that are systematic and controlled, are careful and logical, objective and empirical and are directed at the goals to be solved. The research carried out should be able to answer existing problems, reveal correctly or predict correctly. (Muri Yusuf, 2014: 24).

This study aims to examine the effect of the independent variable, namely reliability, assurance, tangible, empathy, responsiveness to the dependent variable, namely consumer loyalty.

The population in this study were Shopee consumers in Jabodetabek. Sampling in this study using the Slovin method, using a value of $90 \%$ confidence level and of $10 \%$. Respondents used in this study are shopee consumers who live in Jabodetabek. The data were obtained using a questionnaire that was distributed directly to shopee consumers in Jabodetabek. So the total sample used in this study was 100 respondents.

\section{Operational Definition of Variables Reliability}

Reliability relates to the company's ability to provide accurate service from the first time without making any mistakes and deliver its services according to the agreed time. (Pasuraman, Zeithmal, and Berry in the book Tjiptono, Chandra, 2011: 198)

\section{Assurance}

Assurance, with respect to the knowledge and courtesy of employees and their ability to foster trust and customer confidence. (Pasuraman, Zeithmal, and Berry in the book Tjiptono, 2012: 175)

\section{Tangible (Conclusive evidence)}


Tangible with respect to the attractiveness of the physical facilities, equipment and materials used by the company, as well as the appearance of employees. (Pasuraman, Zeithmal, and Berry in the book Tjiptono, Chandra, 2011: 198)

\section{Empathy}

Empathymeans that the company understands the problems of its customers and acts in the interest of the customers, and pays personal attention to customers and has comfortable hours of operation. (Pasuraman, Zeithmal, and Berry in the book Tjiptono, Chandra, 2011: 198)

\section{Responsiveness}

Responsiveness, refers to the willingness and ability of service providers to help customers and respond to their requests immediately. (Pasuraman, Zeithmal, and Berry in the book Tjiptono, 2012: 175)

\section{Consumer Loyalty}

According to Kotler and Keller (2009: 138)expressing loyalty is "a deeply held commitment to buy or repurchase a preferred product or service in the future even though the influence of the situation and marketing efforts have the potential to cause customers to switch".

\section{Data analysis technique}

This study uses multiple regression analysis. Here is the regression equation

$$
\mathrm{Y}=\beta 0+\beta 1 \mathrm{X} 1+\beta 2 \mathrm{X} 2+\beta 3 \mathrm{X} 3+\beta 4 \mathrm{X} 4+\beta 5 \mathrm{X} 5+\mathrm{e}
$$

Y : Consumer Loyalty

$\beta 0, \beta 1, \beta 2, \beta 3, \beta 4, \beta 5$ : Constants/ Slope

$\begin{array}{ll}\mathrm{X} 1 & : \text { Reliability } \\ \mathrm{X} 2 & \text { : Assurance } \\ \mathrm{X} 3 & \text { : Tangible } \\ \mathrm{X} 4 & \text { : Empathy } \\ \mathrm{X} 5 & \text { : Responsiveness } \\ \mathrm{e} & \text { : Random error (error term) }\end{array}$

\section{FINDINGS AND DISCUSSION}

Respondent Profile Characteristics

Respondents in this study were Shopee consumers who live in Jabodetabek. The following is a description of the identity of the research respondents consisting of gender, age, place of residence, and occupation. In the following table a description of the respondents is presented:

Table 1. Respondent Description Test Results

\begin{tabular}{|l|l|c|c|}
\hline NO & \multicolumn{1}{|c|}{ Respondent Description } & amount & Percentage \\
\hline 1. & Respondent Gender: & & \\
& Male & 22 & $22 \%$ \\
& Women & 78 & $78 \%$ \\
\hline
\end{tabular}




\begin{tabular}{|l|l|c|c|}
\hline 2. & Respondents Age: & 11 & $11 \%$ \\
& $<18$ Years & 85 & $85 \%$ \\
& $18-25$ Years & 4 & $4 \%$ \\
\hline 3. & Respondent Residence: & & \\
& Jakarta & 47 & $47 \%$ \\
& Bogor & 16 & $16 \%$ \\
& Depok & 7 & $7 \%$ \\
& Tangerang & 17 & $17 \%$ \\
& Bekasi & 13 & $13 \%$ \\
\hline 4. & Respondent Occupation: & 76 & $76 \%$ \\
& Student / Student & 1 & $1 \%$ \\
& Government employees & 15 & $15 \%$ \\
& Employees / wati & 2 & $2 \%$ \\
& Entrepreneur & 6 & $6 \%$ \\
\hline
\end{tabular}

Source: Data processed, 2020

Based on the table above. It is known that most of the respondents were female as many as 78 people (78\%) and male as many as 22 people (22\%). Most respondents were 18-25 years old, namely 85 people $(85 \%), 11$ people $<18$ years old $(11 \%)$ and 4 people $>25$ years old $(4 \%)$. While the majority of respondents live in Jakarta as many as 47 people (47\%), second is Tangerang with 17 people (17\%), third is Bogor with 16 people (16\%), fourth is Bekasi with 13 people (13\%), and the fifth is Depok with 7 people (7\%). Most respondent occupations are students / students, namely 76 people (74\%), the second employee as many as 15 people $(15 \%)$, the third is Others as many as 6 people $(6 \%)$, the four entrepreneurs as many as 2 people $(2 \%)$, and Fifth, Civil Servants, 1 person (1\%).

\section{HYPOTHESIS TEST RESULTS}

Determination Coefficient Test

Table 2. Coefficient of Determination(R2)

\begin{tabular}{ll}
\hline \hline R-squared & 0.844223 \\
Adjusted R-squared & 0.835937 \\
\hline
\end{tabular}

Source: Results of data processing eviews 7, 2020

From the results of these calculations, the influence of the independent variable on the dependent variable which can be explained by the model in this equation is 0.844223 or $84.42 \%$. This shows that the variations of the Reliability, Assurance, Tangible, Empathy, and Responsiveness variables are able to explain the variation in the rise / fall of Consumer Loyalty by $84.42 \%$ while the remaining $15.58 \%$ is explained by factors other than Reliability, Assurance, Tangible, Empathy, and Responsiveness which is not included in this regression model

Table 3. Hypothesis Test (Partial t)

Dependent Variable: Customer_Loyality

Method: Least Squares

Sample: 1100

Included observations: 100

\begin{tabular}{ccccc}
\hline \hline Variable & Coefficient & Std. Error & t-Statistic & Prob. \\
\hline \hline C & 0.612246 & 0.985983 & 0.620950 & 0.5361 \\
Reliability & 0.276142 & 0.101646 & 2.716690 & 0.0078 \\
Assurance & 0.272123 & 0.072303 & 3.763653 & 0.0003
\end{tabular}




\begin{tabular}{ccccc} 
Tangible & 0.352068 & 0.077891 & 4.520024 & 0.0000 \\
Empathy & 0.263962 & 0.088940 & 2.967872 & 0.0038 \\
Responsiveness & 0.275883 & 0.069718 & 3.957148 & 0.0001 \\
\hline \hline
\end{tabular}

Source: Results of data processing eviews 7, 2020

From the calculation results for the $t$ test of the Reliability variable, it is obtained that the tcount is 2.716690 with a probability of 0.0078 . So it can be concluded that tcount (2.716690)> ttable (1.98552), which means rejecting H0 and accepting H1. So that the first hypothesis put forward states that there is an effect of Reliability on Shopee E-Commerce Consumer Loyalty during the Covid 19 Period, it can be accepted.

The following is the calculation for the $t$ test of the Assurance variable, it is obtained tcount of 3.763653 with a probability of 0.0003 . Then it can be concluded that $t$-count (3.763653)> t-table (1.98552), which means rejecting $\mathrm{H} 0$ and accepting $\mathrm{H} 1$. So that the second hypothesis that is put forward states that there is an effect of Assurance on Shopee E-Commerce Consumer Loyalty during the Covid 19 Period, it can be accepted.

Following is the calculation for the $t$ test of the Tangible variable, the tcount is 4.520024 with a probability of 0.0000 . So it can be concluded that tcount (4.520024)> ttable (1.98552), which means rejecting $\mathrm{H} 0$ and accepting $\mathrm{H} 1$. So that the third hypothesis proposed that there is a Tangible influence on Shopee E-Commerce Consumer Loyalty during the Covid 19 Period, can be accepted.

The following is the calculation for the $t$ test of the Empathy variable, the tcount is 2.967872 with a probability of 0.0038 . So it can be concluded that tcount (2.967872)> ttable (1.98552), which means rejecting $\mathrm{H} 0$ and accepting H1. So that the fourth hypothesis put forward states that there is an influence of Empathy on Shopee E-Commerce Consumer Loyalty during the Covid 19 Period, can be accepted.

Furthermore, the calculation results for the t test of the Responsiveness variable obtained t count of 3.957148 with a probability of 0.0001 . So it can be concluded that tcount (3.957148)> ttable (1.98552), which means rejecting H0 and accepting H1. So that the fifth hypothesis proposed states that there is an effect of Responsiveness on Shopee E-Commerce Consumer Loyalty during the Covid 19 Period, it can be accepted.

\section{Statistical Test Results F}

The F statistical test is used to determine the effect of all independent variables included in the regression model together on the dependent variable tested at a significant level of 0.05 . In the following table, the results of the F statistical test are presented.

Table 4. Hypothesis Test (Simultaneous f)

\begin{tabular}{ll}
\hline \hline F-statistic & 101.8855 \\
Prob (F-statistic) & 0.000000
\end{tabular}

Source: Results of data processing eviews 7, 2020

From the results of these calculations, it can be seen that the results of the Fcount test are 101.8855 with a probability of 0.000000 . So it can be concluded that Fcount (101.8855)> Ftable (2.31), which means rejecting H0 and accepting H1. So that the sixth hypothesis proposed that there is an effect of Reliability, Assurance, Tangible, Empathy, and 
Responsiveness together on Shopee E-Commerce Consumer Loyalty during the Covid 19 Period, can be accepted.

\section{CONCLUSIONS AND SUGGESTIONS Conclusion}

The conclusions that can be drawn regarding the influence of Reliability, Assurance, Tangible, Empathy and Responsiveness on Shopee E-Commerce Consumer Loyalty during the Covid 19 Period are as follows: Reliability (X1) partially has a positive and significant correlation coefficient value on Consumer Loyalty, Assurance ( X2) partially has a positive and significant correlation coefficient value for Consumer Loyalty, Tangible (X3) partially has a correlation coefficient value that is significant and significant for Consumer Loyalty, Empathy (X4) partially has a positive and significant correlation coefficient value for Consumer Loyalty, Responsiveness (X5) partially has a positive but significant correlation coefficient value towards Consumer Loyalty, Relialibility, Assurance, Tangible, Empathy, and Responsiveness together have an effect on Consumer Loyalty, from the test of the coefficient of determination it appears that the variables Relialibility, Assurance, Tangible, Empathy, and Responsiveness are able to explain variations in the rise / fall of Consumer Loyalty by 0.844223 or $84.42 \%$, while the remaining $15.58 \%$ explained by factors other than Relialibility, Assurance, Tangible, Empathy, and Responsiveness which are not included in this regression model.58\% is explained by factors other than Relialibility, Assurance, Tangible, Empathy, and Responsiveness which are not included in this regression model.58\% is explained by factors other than Relialibility, Assurance, Tangible, Empathy, and Responsiveness which are not included in this regression model.

\section{Suggestion}

After conducting this research, the researcher has several suggestions (1) For readers, this research is expected to add new knowledge about what can affect the loyalty of a consumer in using the services of a company. Where the variables Reliability , Assurance, Tangible , Empathy and Responsiveness can be an influence in determining consumer loyalty. (2) For Shopee E-Commerce, this study illustrates that Reliability, Assurance, Tangible, Empathy and Responsiveness have a positive effect on the satisfaction of Shopee's E-Commerce users. In addition, this research can also be a benchmark for companies to advance opportunities in Indonesia which are getting tougher because currently there are so many E-Commerce options. Evaluating and creating new innovations, both making the system safer, and various attractive features to attract consumer attention will be a huge opportunity to increase sales on Shopee's E-Commerce. (3) For further researchers, it is hoped that it can be used as a reference for further research to be developed by adding observation periods, applying different objects, and adding other variables besides Reliability, Assurance, Tangible, Empathy, and Responsiveness.

\section{REFERENCE}

Ariefianto, Moch. Doddy. Ekonometrika: Esensi dan Aplikasi dengan menggunakan Eviews. Penerbit Erlangga. Jakarta. 2012.

Arif. M Nur Rianto Al. Dasar-Dasar Pemasaran Bank Syariah. Alfabeta. Bandung, 2012.

Arisandy, Yosi, Andi Harpepen, \& Adhadi Kurniawan. Sistem Informasi Manajemen (Teori dan Implementasi dalam Bisnis). Pustaka Pelajar. Yogyakarta. 2017.

Caruana, A. (2002). Service loyalty: The effects of service quality and the mediating role of customer satisfaction. European Journal of Marketing.

Creswell, J. (2013). Qualitative, quantitative, and mixed methods approaches. In Research design. 
Gefen, D. (2002). Customer Loyalty in E-Commerce. Journal of the Association for Information Systems.

Heale, R., \& Twycross, A. (2015). Validity and reliability in quantitative studies. EvidenceBased Nursing.

Hurriyati, Ratih. Bauran Pemasaran dan Loyalitas Konsumen. Alfabeta. Bandung. 2010.

Khorista, Afrinda, Edy Yulianto, \& M. Kholid Mawardi. Pengaruh Kualitas Pelayanan Terhadap Kepuasan Pelanggan (Survey Pada Pelanggan Fedex Express Surabaya). Fakultas Ilmu Administrasi Universitas Brawijaya Malang. Jurnal Administrasi Bisnis, Vol. 25 No. 2, Agustus 2015.

Kotler, Philip, \& Kevin Lane Keller. Manajemen Pemasaran. Erlangga. Jakarta. Edisi 13 Jilid 1. 2009.

Lovelock, Christopher, Jochen Wirtrz, \& Jacky Mussry. Pemasaran Jasa Manusia, Teknologi, Strategi. Erlangga. Jakarta. Edisi 7 Jilid 2. 2013.

Lupiyoadi, Rambat. Manajemen Pemasaran Jasa. Salemba Empat. Jakarta. Edisi 3. 2013.

Marina, Sandriana, Andi Darmawati, \& Indra Setiawan. Pengaruh Kualitas Pelayanan Terhadap Loyalitas Pelanggan pada Perusahaan Penerbangan Full Service Airlines. Jurnal Manajemen Transportasi \& Logistik Vol. 01 No. 02, Juli 2014.

Panjaitan, Januar Efendi, \& Ai Lili Yuliati. Pengaruh Kualitas Pelayanan Terhadap Kepuasan Pelanggan Pada JNE Cabang Bandung. Prodi Administrasi Bisnis, Fakultas Komunikasi dan Bisnis Universitas Telkom Bandung, DaReMa Jurnal Manajemen Vol. 11 No. 2, September 2016.

Pratama, Bagaskara, Hendy Tannady, \& Panca Jodiawan. Analisis Pengaruh Kualitas Pelayanan Terhadap Kepuasan Pelanggan (Studi Kasus di NN Laundry, Jakarta Selatan. Program Studi Teknik Manajemen Industri Universitas Bunda Mulia Jakarta, Vol. 06 No. 24, Okt-Des 2017.

Rahmayanty, Nina. Manajemen Pelayanan Prima. Graha Ilmu. Yogyakarta. 2010.

Sigit P, Reza Dimas, \& Farah Oktafani. Pengaruh Kualitas Pelayanan Terhadap Kepuasan Pelanggan Pengguna Jasa Lapangan Futsal (Studi Kasus IFI Futsal Bandung). Fakultas Ekonomi dan Bisnis Universitas Telkom Bandung. 2014.

Sugiarto. Metodologi Penelitian Bisnis. ANDI. Yogyakarta. 2017.

Sumarwan, Ujang, et al. Pemasaran Strategik: Perspektif Value-Based Marketing \& Pengukuran Kinerja. IPB Press. Bogor. 2011.

Tjiptono, Fandy, \& Gregorius Chandra. Service, Quality \& Satisfaction. ANDI. Yogyakarta. Edisi 3. 2011.

Tjiptono, Fandy. Service Management Mewujudkan Layanan Prima. ANDI. Yogyakarta. Edisi 2. 2012. Widarjono, Agus. Ekonometrika: Pengantar dan Aplikasinya. UPP STIM YKPN. Yogyakarta. 2013.

Wijaya, David. Pemasaran Jasa Pendidikan. Salemba Empat. Jakarta. 2012 www. Indonesia Internet Exchange.or.id. (10 April 2020) 